\title{
Enhancing Concentration through Dayak's Beaded Crafts
}

\author{
D.N. Rahayu \\ Universitas Mulawarman \\ Samarinda, Indonesia \\ $A S$ \\ Universitas Mulawarman \\ Samarinda, Indonesia
}

\author{
P A Putri \\ Universitas Negeri Surabaya \\ Surabaya, Indonesia \\ L Puji \\ Universitas Mulawarman \\ Samarinda, Indonesia
}

\begin{abstract}
The purpose of this study is to find out the concentration enhancement of Elementary Students after they were given the Dayak's beaded craft beading training. The design of the study is quantitative by experimental approach. The sample of this research was 30 elementary students of SD 001 Samarinda Ilir. The technique of the data analysis had been used in this research was $\mathrm{T}$ Test. The result of this research showed that there is concentration enhancement of subject after they were given the activity of making Dayak's beaded pen's sleeve with t count value $=4.742$ by means of $p$ $=0.000$ so $H_{0}$ is rejected and $H_{1}$ is accepted, that means there is difference in the students' concentration level, and after they were given the activity of making Dayak's beaded wristband the $t$ count gained= 5.810 by means of $p=0.000$ so $H_{0}$ is rejected and the $H_{1}$ is accepted, that means there was difference in concentration level among students of SDN 001 Samarinda Ilir.
\end{abstract}

\section{Keywords-Concentration; Dayak's Beaded Crafts}

\section{INTRODUCTION}

Each student has a potential to earn achievement. Achievement will be gained if they have a good reading skill, writing skill, arithmetic and listening skills that previously gained from learning process [12]. At school, teacher also support fully in giving lesson based on their need that will help them earning a good achievement [13].

Students should to be able to concentrate during learning process. Slameto (2010) stated that a focus during the learning process gives big impact to learning outcome. If someone experienced difficulty in concentration, the learning process would be meaningless, the time, expenses and effort which had spent would be useless. Someone who could study well is someone who can concentrate well, in other words s/he must have an ability to focus their mind to the lesson which is an ability that every student should have when studying.

Concentration enhancement could be done through Dayak's beaded craft activities. This activity could train fine motor skill. Fine motor skill is the movement that requires only certain small muscles that need a good coordination of movement and a good ability to concentrate [1]. Some activities that related to children's fine motor skill are writing, drawing, beading, weaving and so on [3].

Dayak's beaded craft which made by beading technique has a function as East Kalimantan special craft, such as bag, necklace, bracelet, and many more. At the past time, Dayak's beaded craft only wore by King's descendants as supernatural charm and accessories in their house in form of bracelet and necklace. They also used it as a baby sling, they believe it would be prevented the baby from any supernatural threat and dangerous disease. Only a few of common folks wore it [6].

Dayak's beaded craft which made by beading could train fine motor skill also. Beading activity requires eyes and hands coordination along with accuracy, focus, meticulousness and also concentration. In beading activity, they need to string the beads one by one using the thread. In such a way, they can move their arms and hands flexibly by following the winding pattern.

Finger muscles and suppleness skill belongs to fine motor skill $[10,11]$. The more children do beading activity the more children fine motor skill enhancing. Moreover, students who get Dayak's beaded activity hopefully they could enhance their concentration too. It will make the learning process in the class running better and students will earn more achievement when the students can concentrate well.

\section{METHOD}

The sample of this research is 30 students that divided into two groups, which are: 15 students who will be given an instruction to make Dayak's beaded pen's sleeve and 15 students who will get an instruction to make Dayak's beaded wristband. 
The data collecting tool in this research uses a concentration scale adapted from a concentration scale developed by Amalia Cahya Setiani in 2014 [5]. The answers in this scale are made up of 5 choices which are arranged into a Likert scale [14] and the subject is asked to measure on which level they think they experience each condition that is given in the last one week.

The scale also is consisted of two groups of items for every aspect or indication which are favorable items and unfavorable items. The score range in this scale is from 1 to 5 . The favorable items have 5 for very suitable answer (SS), 4 for Suitable answer (S), 3 for the answer Between Suitable and unsuitable (E), 2 for unsuitable answer (TS), and 1 for very unsuitable answer (STS). However, for unfavorable items have 1 for very suitable answer (SS), 2 for suitable answer (S), 3 for the answer between suitable and unsuitable (E), 4 for unsuitable answer (TS), and 5 for very Unsuitable answer (STS). The assessment in this measurement tool is in accordance with the standardized norm and the research location, as seen on the table below:

TABLE I. THE NORMS OF CONCENTRATION ENHANCEMENT LEVEL

\begin{tabular}{cc}
\hline Interval & Criteria \\
\hline$>180$ & Very High \\
$150-179$ & High \\
$120-149$ & Moderate \\
$90-119$ & Low \\
$<90$ & Very Low \\
\hline
\end{tabular}

The higher the total score the students get from the concentration scale, the higher their concentration level in the process of learning. In the contrary, the lower the concentration score they get, the lower the concentration level they have in the learning process.

The data analysis technique that is used in this study is TTest statistical analysis. Before the hypothesis test is being conducted, the descriptive test, normality test, and homogeneity test are being done beforehand assisted by computer program called SPSS (Statistical Packages for Social Science) version 20.0 for windows [15].

\section{RESULTS AND DISCUSSION}

\subsection{The Result of Normality Test}

Normality test was used to see the observation frequency deviations which are examined from the theoretical frequencies. The assumptions of normality test applied analytical statistical test of Shapiro-Wilk normality test because the subject was less than 50 . The rule used was if $p>$
0.05 then the distribution is normal and if $\mathrm{p}<0.05$ then the distribution is not normal (Santoso, 2015)

TABLE II. The RESUlt OF NoRMALITy TEST

\begin{tabular}{|c|c|c|c|c|c|c|c|}
\hline \multirow[t]{2}{*}{ Category } & \multirow{2}{*}{$\begin{array}{l}\text { Types of } \\
\text { Activity }\end{array}$} & \multicolumn{3}{|c|}{ Shapiro-Wilk } & & & \\
\hline & & Statistic & df & Sig. & & & \\
\hline \multirow[t]{2}{*}{ Pre-Test } & $\begin{array}{l}\text { Pen's } \\
\text { Sleeve }\end{array}$ & 0.984 & 15 & 0.500 & & & \\
\hline & Wristband & 0.965 & 15 & 0.773 & & & \\
\hline \multirow[t]{2}{*}{$\begin{array}{l}\text { Post-Test } \\
\text { Activity } \\
\text { Period } 1\end{array}$} & $\begin{array}{l}\text { Pen's } \\
\text { Sleeve }\end{array}$ & 0.946 & 15 & 0.470 & & & \\
\hline & Wristband & 0.984 & 15 & 0.494 & & & \\
\hline \multirow[t]{2}{*}{$\begin{array}{l}\text { Post-Test } \\
\text { Activity } \\
\text { Period } 2\end{array}$} & $\begin{array}{l}\text { Pen's } \\
\text { Sleeve }\end{array}$ & 0.977 & 15 & 0.944 & & & \\
\hline & \multicolumn{4}{|c|}{ Wristband } & 0.984 & 15 & 0.486 \\
\hline
\end{tabular}

Table II can be interpreted as follows:

1. The result of assumptions test of normality distribution to the concentration variable of Pre-test of beaded pen's sleeve yield the value of $p=0.500(p>0.05)$ and Pre-test of beaded wristband resulted the value of $p=0.773$ ( $p>$ 0.05). Based on the rules, this result shows the distribution of the concentration variables items of pretest is normal.

2. The result of assumptions test of normality distribution to the concentration variable of Post-test of beaded pen's sleeve making activity in 1st period resulted the value of $\mathrm{p}=0.470$ ( $\mathrm{p}>0.05)$ and Post-test of beaded wristband making activity in 1 st period produced $\mathrm{p}=0.494(\mathrm{p}>$ $0.05)$. The results of the test, based on the rules, show that the distribution of the items of the post-test concentration of the 1 st period of beading activity is normal.

3. The result of assumptions test of distribution normality to concentration variable of Post-test of beaded wristband making activity in 2 nd period resulted the value of $\mathrm{p}=$ 0.944 ( $p>0.05$ ) and Post-test of beaded pen's sleeve making activity in 2 nd period yield the value $\mathrm{p}=0.486$ $(p>0.05)$. The results of the test, based on the rules, show that the distribution of the items of the post-test concentration of the 2 nd period of beading activity is normal.

Based on table II, it can be deduced that all three distributions of pre-test and post-test of 1st beading activity period, and post-test of 2 nd beading activity period have a normal distribution, thus parametric data analysis can be done because it has been qualified for the assumptions of the normality distribution of the research data. 


\subsection{The Result of Homogeneity Test}

The homogeneity test was intended to show that two or more groups of sample data come from the populations which have equal variation. In this research, the homogeneity between the low-level and high-level groups was tested, in order to know that the data of the two groups had an equal variation. The homogeneity test rule was, variable data was considered homogeneous, when the $\mathrm{p}>0.05$. The calculation used level test method, the result of $\mathrm{T}$ Test presented in Table III below.

TABLE III. THE RESUlT OF HOMOGENEITY TEST

\begin{tabular}{llll}
\hline Levene Statistic & df1 & df2 & Sig. \\
\hline 1.171 & 1 & 28 & 0.288 \\
\hline
\end{tabular}

According to table 3 above, the result of calculation on pen's sleeve group and wristband group is $p=0.288(p>50)$ which implies that the concentration variable data is homogeneous.

\subsection{The Result of Hypothesis Test}

The hypothesis in this research was to find out the differences of students' concentration level of SDN 001 Samarinda Ilir before and after being given training of Dayak's beaded crafts in the forms of pen's sleeve. In this research, the hypothesis test rule for paired sample t-test is if $p>0.05$ then $\mathrm{H} 0$ was accepted and if $p<0.05$ then $\mathrm{H} 0$ was rejected [4].

TABLE IV. The RESUlt OF PAIRED T-TEST FOR PEN’s SLEEVE GrouP

\begin{tabular}{llllll}
\hline & \multicolumn{5}{l}{ Paired Sample t-Test } \\
\cline { 2 - 6 } & $\begin{array}{l}\mathrm{t} \\
\text { calculate }\end{array}$ & $\begin{array}{l}\mathrm{t} \\
\text { table }\end{array}$ & df & Sig. & $\begin{array}{l}\text { Mean } \\
\text { Difference }\end{array}$ \\
\hline $\begin{array}{l}\text { Pre-Test - Post Test Activity } \\
\text { Period 1 }\end{array}$ & 4.742 & 2.145 & 14 & 0.000 & 40.333 \\
$\begin{array}{l}\text { Post Test Activity Period 1 - } \\
\text { Post Test Activity Period 2 }\end{array}$ & 2.014 & 2.145 & 14 & 0.064 & 9.333 \\
\hline
\end{tabular}

Based on Table IV, it can be seen that in the pre-test and posttest of the first period of beading pen's sleeve activity, the result of $\mathrm{t}$ value is $4.742(>\mathrm{t}$ table $=2.145)$ with $p=0.000(p>$ $0.05)$ so $\mathrm{H}_{0}$ is rejected and $\mathrm{H}_{1}$ is accepted, that means there is difference in the students' concentration level after being given the activity of Dayak's beaded pen's sleeve. While in posttest of first period activity and posttest of second period activity the $\mathrm{t}$ value is $2.014(>\mathrm{t}$ table $=2.145)$ with $p=0.064(p>$ $0.05)$ so $\mathrm{H} 0$ is accepted and caused the $\mathrm{H} 1$ rejected, which means there was no difference in the students' concentration level after being given a beading activity of making Dayak's beaded pen's sleeve.

The second hypothesis in this research was to recognize the differences of students' concentration level of SDN 001 before and after being given the Dayak's beaded wristband activity. In this research, the hypothesis test rule for paired $t$ sample t-test is if $p>0.05$ then H0 is accepted and if $p<0.05$ then $\mathrm{HO}$ is rejected [4].
TABLE V. The Result of PAired SAmple T-Test For BeAded WRISTBAND GROUP

\begin{tabular}{lllllll}
\hline & \multicolumn{3}{l}{ Paired Sample t-Test } & & \\
\cline { 2 - 6 } & & $\begin{array}{l}\mathrm{t} \\
\text { calculates }\end{array}$ & $\begin{array}{l}\mathrm{t} \\
\text { table }\end{array}$ & Df & Sig. & $\begin{array}{l}\text { Mean } \\
\text { Difference }\end{array}$ \\
\hline $\begin{array}{l}\text { Pre-Test }- \text { Post } \\
\text { Activity Period 1 }\end{array}$ & Test & 5.810 & 2.145 & 14 & 0.000 & 55.000 \\
$\begin{array}{l}\text { Post Test Activity Period } \\
\begin{array}{l}1-\text { Post Test Activity } \\
\text { Period 2 }\end{array}\end{array}$ & 8.733 & 2.145 & 14 & 0.080 & 1.890 \\
\hline
\end{tabular}

Based on table $\mathrm{V}$, it can be seen that in the pre-test and posttest of the first period of beading Dayak's wristband activity the result of $\mathrm{t}$ value is $5.810(>\mathrm{t}$ table $=2.145)$ with $p$ $=0.000(p<0.05)$ so $\mathrm{H} 0$ was rejected, cause $\mathrm{H} 1$ accepted which means there was difference in concentration level among students of SDN 001 Samarinda Ilir after being given the activity of Dayak's beaded wristband. On the other hand, in the post-test of the first period activity and posttest of the second period activity of beading Dayak's beaded wristband, the result of $\mathrm{t}$ value is $8.733(>\mathrm{t}$ table $=2.145$ ) with $p=0.080$ $(p<0.05)$ so $\mathrm{H} 0$ is accepted, cause $\mathrm{H} 1$ is rejected which means there was no difference in concentration level among students of SDN 001 Samarinda Ilir after being given a beading activity of making Dayak's beaded wristband.

The hypothesis in this study was to know whether there was an increase of concentration on the subject who is given the activity of making Dayak's beaded crafts in the form of pen's sleeve and beaded wrist-band. The results of the data analysis show an increase of concentration level on the students of SDN001 Samarinda Ilir after the activity of making Dayak's beaded pen's sleeve.

Based on the result of data analysis of pre-test and posttest of first period beading activity of making Dayak's beaded pen's sleeve, using paired t-test, the result of t calculated is $4.742(>\mathrm{t}$ table $=2.145)$ with $p=0.000(p>0.05)$ so that $\mathrm{H}_{0}$ is rejected and so $\mathrm{H}_{0}$ is accepted, cause $\mathrm{H}_{1}$ is rejected which means there is no difference in concentration level among students of SDN 001 Samarinda Ilir after being given a beading activity of making Dayak's beaded wristband.

Based on the result of data analysis of pre-test and posttest of first period beading activity of making Dayak's beaded pen's sleeve, using paired t-test, the result of t calculated is $4.742(>\mathrm{t}$ table $=2.145)$ with $p=0.000(p>0.05)$ so that $\mathrm{H}_{0}$ is rejected and $\mathrm{H}_{1}$ is accepted which means there is difference in students' concentration level after being given the activity of Dayak's beaded pen's sleeve. However, in posttest of first period activity and posttest of second period activity, it can be seen that $\mathrm{t}$ calculate is $2.014(>\mathrm{t}$ table $=2.145)$ with $p=0.064$ ( $p>0.05$ ) so $\mathrm{H}_{0}$ is accepted, cause $\mathrm{H}_{1}$ is rejected which means there is no difference in students' concentration level after being given a beading activity of making Dayak's beaded pen's sleeve. 
The result of the data analysis described that there is a difference of concentration level on the students of SDN 001 Samarinda Ilir after they took part in the making of Dayak's beaded wristband. According to the result of the data analysis of pre-test and post-test from the first period beading activity of making Dayak's beaded wristband using paired t-test, the $\mathrm{t}$ calculated is $5.810(>\mathrm{t}$ table $=2.145)$ with $p=0.000(p<$ $0.05)$ so $\mathrm{H}_{0}$ is rejected, cause $\mathrm{H}_{1}$ accepted which means there is difference in concentration level among students of SDN 001 Samarinda Ilir after being given the activity of Dayak's beaded wristband. On the other hand, in posttest of first period activity and posttest of 2nd period activity of beading Dayak's beaded wristband, the result of $\mathrm{t}$ calculate is $8.733(>\mathrm{t}$ table $=$ $2,145)$ with $p=0.080(p<0.05)$ so $\mathrm{H}_{0}$ is accepted, cause $\mathrm{H}_{1}$ is rejected which means there is no difference in concentration level among students of SDN 001 Samarinda Ilir after being given a beading activity of making Dayak's beaded wristband.

Based on the result of hypothesis test, it shows that there is a concentration enhancement. This is supported by the score data and concentration classification in the pen's sleeve group, there are 11 students who experience an enhancement of concentration and 4 students who experience constant concentration level. In wristband group, there are 10 students who experience an enhancement of concentration and 5 students who experience constant concentration level.

A study which is conducted by Endayanti (2013) stated that beading activity is aimed to enhance the coordination of children's eyes and hands movement. Sometime children's enthusiasm will decrease during beading activity because in such activity concentration and patient are needed to string beads or hold the small items like beads. Beading activity does not only need a coordination of eyes and hands but also a precision, focus, accuracy, and a concentration are necessity to do it [9]. Through beading activity, children's fingers will become skillful when they have to string the beads one by one using the thread. In such a way, they can move their arms and hands flexibly by following the winding pattern.

The activity of making Dayak's beaded on the second period, in which the experimental group who had been given an activity of making Dayak's beaded pen's sleeve on 1st period, would be given a different activity which was making Dayak's beaded wristband. The same went for the experimental group who had been given an activity of making Dayak's beaded wristband on the first period. They would be given an activity of making Dayak's beaded pen's sleeve. This second period of beading activity resulted a finding that after giving the students a different beading activity, their concentration level didn't change. This is supported by the score data and concentration classification in which for pen's sleeve group on the second period, there are 4 students who experience an enhancement of concentration, 11 students who experience constant concentration level, and 4 students who underwent a concentration decrease. Whereas in wristband group on the second period, there are 3 students who experience an enhancement of concentration, 10 students who stay on constant concentration level, and 2 students from experimental group whose concentration level decrease.

Crafting Dayak's beaded pen's sleeve and beaded wristband use the same technique, but both have different levels of difficulty. The process of making Dayak's beaded wristband is easier, since it does not have a certain pattern even though it carries the col- or of Dayak's signature design. Whilst the pen's sleeve is more difficult, it requires more precision and concentration, because it has a certain counted pattern which depicts Dayak's signature design of accoiled snake [9].

This is supported by Uyang (2016) who suggests that the making of Dayak's beaded crafts by beading technique that demands a coordination of eyes and hands movement along with a precision, focus, accuracy, and a good concentration at both the hardest and the easiest levels. Because beading is basically an activity to string beads one by one to one thread to create a concrete object (Sofyan, 1994). Dayak's beaded crafts making activity was given to the subject used tools and materials with the same quality on the first and second period of beading activity.

\section{CONCLUSION}

Considering the result of the study that has been conducted, it can be concluded that:

1. There was a concentration enhancement to the subject who has been given first period activity of making Dayak's beaded pen's sleeve.

2. There was a concentration enhancement to the subject who has been given first period activity of making Dayak's beaded wristband.

3. There was no concentration enhancement to the subject who has been given second period activity of making Dayak's beaded pen's sleeve.

4. There was a concentration enhancement to the subject who has been given second period activity of making Dayak's beaded wristband.

\section{REFERENCES}

[1] Astati, Terapi okupasi, bermain dan musik untuk anak tunagrahita. Bandung: Depdikbud, 1995.

[2] I. S. Endayanti, "Meningkatkan kemampuan motorik halus melalui kegiatan meronce pada anak kelompok ber-main Masjid Syuhada". Skripsi. Fakultas Ilmu Pendidikan: Univeritas Negeri Yogyakarta, 2013.

[3] Samsudin, Pengembangan motorik di Taman Kanak-Kanak. Jakarta: Universitas Negeri Jakarta, 2005.

[4] S. Santoso, Menguasai statistik parametik. Jakarta: PT. Gramedia, 2015.

[5] A. C. Setiani, "Meningkatkan konsentrasi belajar melalui layanan bimbingan kelompok". Skripsi. Fakultas Ilmu Pendidikan, Universitas Negeri Semarang: Semarang, 2014.

[6] A. Simon, Kerajinan khas Dayak". Samarinda: Samarinda Press, 2016

[7] Slameto, Belajar dan faktor-faktor yang mempengaruhinya. Jakarta: Rineka Cipta, 2010.

[8] P. Y. Sofyan, Penuntun belajar kerajinan tangan dan kesenian 4. Bandung: Ganeca Exact Bandung, 1994. 
[9] Uyang, Manik-manik khas Dayak. Samarinda: Samarinda Press, 2016.

[10] S. Houwen, E. Hartman, and C. Visscher, "Physical activity and moto skills in children with and without visual impairments" in Medicine and Science in Sports and Exercise Vol 41 (1), pp. 103-109, 2009.

[11] S Houwen, C Visscher, K A Lemmink, and E Hartman, "Motor skill performance of school-age children with visual impairments" in Developmental Medicine and Child Neurology, Vol. 50 (2), pp 139. $145,2008$.

[12] David A. Kolb, "Management and the Learning Process" in California Management Review Spring, Vol. 18 No. 3, 1976.
[13] H John, B John, and Purdie N, "Effects of Learning Skills Inventions on Student Learning: A Meta-Analysis", 1996.

[14] T Nemoto and D Beglar, "Developing Likert-scale questionnaires", N Sonda \& A. Krause (Eds, in JALT2013 Conference Proceeding. Tokyo: JALT, 2014.

[15] Ho Robert, Handbook of Univariate and Multivariate Data Analysis and Interpretation with SPSS. Boca Raton, Florida: Taylor \& Francis Group, 2006. 